\title{
Pemecahan Masalah Matematika Melalui Metode Defragmenting
}

\author{
Suci Haryanti ${ }^{\left.1^{*}\right)}$
}

${ }^{1}$ SMK PKP JIS

\section{INFO ARTICLES}

Article History:

Received: 17 Februari 2018

Revised: 25 Februari 2018

Approved: 6 Maret 2018

Publish Online: 13 Maret 2018

\section{Key Words:}

Literature study, Defragmenting methods, Mathematical problem solving

\section{(i) (2)}

This article is licensed mons AttributionShareAlike 4.0 International License.

\begin{abstract}
The purpose of the study is to findways to solve mathematical problems to make it easier and fun and also able to remember the concept in the long run with the defragmenter method is to reconstruct the mindset to be easier when used or recalled in solving math problems The method used in this study is literature study by using theoretical study approach. From the study there are three components that obtained : 1) scanning, 2) check some errors, 3) Repairing, 4)give a chance to re-work 5) certain the results.
\end{abstract}

\begin{abstract}
Abstrak: Tujuan dari penelitian adalah untuk menemukan cara memecahkan masalah matematika agar lebih mudah dan menyenangkan juga mampu diingat konsepnya dalam jangka panjang, dengan metode defragmenting yaitu mengkotruksi ulang pola pikir untuk lebih mudah saat ingin di gunakan atau di panggil kembali dalam memecahkan masalah matematika Metode yang digunakan dalam penelitian ini menggunakan studi literature dengan menggunakan pendekatan kajian teoritis. Dari hasil kajian terdapat tiga komponen yang diperoleh yakni : 1) scanning, 2) check some errors, 3) Repairing, 4)give a chance to re-work 5) certain the results
\end{abstract}

Correspondence Address: Jl. Lkr. PKP, RT. 1/RW.8, Klp. Dua Wetan, Ciracas, Kota Jakarta Timur, Daerah Khusus Ibukota Jakarta 13730; e-mail: betasenja1@gmail.com

How to Cite (APA $6^{\text {th }}$ Style): Haryanti. (2018). Pemecahan Masalah Matematika Melalui Metode Defragmenting. JKPM (Jurnal Kajian Pendidikan Matematika), Vol 3 (2), 199-204.

Copyright: Hayanti, S, (2018)

Competing Interests Disclosures: The authors declare that they have no significant competing financial, professional or personal interests that might have influenced the performance or presentation of the work described in this manuscript. 


\section{PENDAHULUAN}

Pada pemecahan masalah matematika seakan terasa sulit sehigga tidak jarang menguras otak untuk berpikir lebih dan tidak sedikit peserta didik atau sebagian orang enggan mengerjakannya padahal baru sekedar membaca soalnya itupun tidak dibaca secara cermat sudah memutuskan untuk menyerah. Menurut Liberna (2015) bahwa banyak orang yang menilai matematika adalah pelajaran yang sulit dan tidak mudah dikuasai, terlebih yang dirasakan oleh siswa. Siswa merasa kurang memiliki minat yang tinggi bila menjumpai soal-soal matematika yang sulit dan bahkan cenderung untuk menghindarinya. Tidak jarang budaya menyontek menjadi berkembang dengan pesat ketika dirasa sudah tidak mampu untuk mengerjakan soal yang bersifat kompleks dalam menjawabnya. Rasa percaya diri yang kian menurun ketika bertemu dengan soal matematika yang dianggap sulit, mematahkan semangat untuk belajar dan terus belajar padahal sejatinya belajar adalah terus mencari tau hal yang tidak di ketahui dan mengadakan perubahan seperti yang teruang dalam pendapat Slameto dalam Suparman (2015) mengatakan bahwa belajar adalah suatu proses usaha yang dilakukan seseorang untuk memperoleh suatu perubahan tingkah laku yang baru secara keseluruhan, sebagai hasil pengalamannya sendiri dalam interkasi dengan lingkungannya. Belajar merupakan proses aktif yang dilakukan untuk memperoleh pengalaman atau pengetahuan baru sehingga dapat menimbulkan terjadinya perubahan tingkah laku (Hudojo, 2003).

Sehubungan dengan itu, menurut Hudojo (2005) dalam belajar matematika terjadi proses berpikir, sebab seseorang dikatakan berpikir bila ia melakukan kegiatan mental. Hal ini sesuai dengan pendapat Kumalasari, dkk (2016) bahwa proses berpikir siswa ditentukan oleh kecukupan struktur berpikir terhadap masalah yang dihadapi. Struktur berpikir adalah representasi dari proses berpikir yang berupa alur penyelesaian masalah yang dilakukan oleh seseorang ketika ia menyelesaikan suatu permasalahan.

Bruner dalam Uno, dkk (2024) yaitu Persoalan inti dari belajar memecahkan masalah matematika terletak pada bagaimana informasi yang didapatkan itu dapat disimpan didalam memori sedemikian rupa sehingga mudah di panggil pada saat di perlukan. Dalam hal ini memori otak yang akan diambil akan mudah di cerna karena di simpan dengan rapih dan file-file akan lebih mudah diambil saat di perlukan dalam memberikan informasi. Sejalan dengan pendapat Bruner diperlukan adanya metode yang mampu mengkontruksi pola pikir agar lebih baik dan rapih sehingga ketika di perlukan akan dengan mudah diambil untuk di gunakan yaitu metode defragmenting . metode yang menggunakan pola pikir untuk lebih bisa bermakna dengan memberi kesempatan peserta didik lebih berinovasi atau mengembangkan pola pikirnya lebih jauh. Hudoyo (2005) berpendapat bahwa dalam pemecahan masalah biasanya ada lima langkah yang ditempuh, yaitu: (a)Menyajikan masalah dalam bentuk yang lebih jelas; (b) Menyatakan masalah dalam bentuk yang lebih operasional; (c) Menyusun hipotesis-hipotesis dan melakukan kerja untuk memperoleh hasilnya, dan (d) Mengecek kembali hasil yang sudah diperoleh. Dalam proses pemecahan masalah, siswa harus menggunakan pengetahuan matematika, kemampuan bernalar dan komunikasi, serta sikap yang baik terhadap matematika. Hal inilah yang dapat melatih siswa untuk terampil dalam menyelesaikan masalah yang dihadapi dalam kehidupan sehari-hari.

Dalam metode defragmenting ini guru memberikan konsep materi ajar matematika kemudian peserta didik di minta mengerjakan tugas, ketika terjadi kesalahan guru tidak serta merta langsung menyalahkan tetapi melakukan pengecekan pada bagian-bagian yang salah, diadakan pendekatan dengan berdialog kepada peserta didik secra individual kenapa bisa terjadi kesalahan dan memberikan kesempatan untuk memperbaiki dengan tidak mengurangi nilai karena dengan peserta didik memperbaiki, peserta didik akan belajar lebih baik lagi lebih memaknai lagi dan bahkan akan terus dingat cara- cara atau langkah - langkah yang peserta didik lakukan dan menanyakan kembali tentang tugas yang dikerjakan. Selvera dalam Kumalasari, dkk (2016) menyatakan bahwa defragmenting struktur berpikir dapat diartikan sebagai restrukturisasi kognitif pada individu. Restrukturisasi kognitif merupakan suatu cara yang dilakukan dengan 
tujuan untuk menata kembali pikiran, menghilangkan keyakinan irrasional yang menyebabkan ketegangan dan kecemasan bagi diri seseorang yang selama ini memengaruhi emosi dan perilakunya. Dalam restrukturisasi kognitif, seseorang diajarkan untuk mengubah kesalahan berpikir sehingga menjadi berpikir realistis.

\section{METODE}

Tulisan ini merupakan studi pustaka yang merupakan telaah dari literature. Metode yang digunakan untuk teknik pengumpulan data dengan mengadakan studi penelahaan terhadap buku-buku literatur-literatur, catatan-catatan, dan laporan-laporan yang ada hubungannya dengan masalah yang dipecahkan.

\section{HASIL}

Berbagai cara untuk lebih memudahkan memecahkan masalah matematika sudah di aplikasikan dengan baik, dalam hal ini defragmenting memberikan nuansa baru dalam metode pembelajaran dengan mengkontruksi ulang pola pikir untuk lebih mudah saat ingin di gunakan atau di panggil kembali seperti pendapat Wahono bahwa Setelah dilakukan defragmentasi, semua dta yang ter-defrag akan saling terhubung dan tertata sehingga memudahkan untuk mengambil dan menjelaskan setiap data yang di panggil. Wahono (2009) Memperjelas cara untuk melakukan dfragmenting otak adalah dengan cara mengingat dan memahami kembali pelajaran yang sudah pernah dipelajari. Mengingat dan memahami pelajaran itu sama saja dengan menghubungkan materi yang sebelumnya terpecah sehingga lebih cepat ketika kita mencari kembali, kadang dalam mengingat kembali cenderung mengalami kesulitan karena tidak semua yang mampu kita ingat dengan baik hanya sedikit dari yang awal di pelajari perlu suatu metode khusus untuk mengatasinya.

Maag mengatakan Defragmenting adalah restrukturasi proses berpikir . restrutur proses berfikir merupakan tehnik yang sering di gunakan untuk mengubah pola pikir yang kurang adaptif pada individu. Metode ini memang belum banyak di gunakan di dunia pendidikan hanya sempat disajikan penelitian oleh beberapa mahasiswa dalam tesis atau skripsi atau karya ilmiah.padahal dalam ilmu matematika sangat perlu suatu metode yang merangsang kemampuan otak mencerna lebih jauh ketingkat kognitif. Defragmenting inilah suatu trobosan baru untuk lebih mudah menstrukturasi kerja otak dalam berpikir.

Menurut Wibawa (2012 : 39) Defragmenting struktur berpikir bertujuan untuk me-restrukturisasi proses berpikir yang terjadi pada siswa. Struktur berpikir siswa yang salah dapat diperbaiki sehingga siswa dapat mengurangi kesalahan yang dilakukan dan bahkan dapat mempertahankan proses berpikirnya. Siswa ketika salah ada yang langsung putus asa dan tidak mau untuk memperbaiki lagi menyerah begitu saja padahal sebenarnya siswa mampu memperbaiki kesalahan pada saat mengerjakan soal matematika.

Sesuai dengan Wibawa pada penelitiannya di SMA N 1 Malang pada semester ganjil tahun 2013/2014. Pada saat itu materi yang diuji adalah materi limit yang dituangkan dalam bukunya yang berjudul Defragmenting Struktur Berpikir Psedo Dalam Memecahkan Masalah Matematika. Wibawa menggunakan penelitian kualitatif dengan instrumen berupa lembar tugas yang dikerjakan siswa sebelum defragmenting dan setelah defragmenting.sangat jelas digambarkan bahwa siswa yang diberi kesempatan untuk memperbaiki kesalahannya dengan cara mengkaji ulang dan mengingat konsep yang telah diajarkan akan lebih mudah dalam memecahkan masalah matematika dan siswa tersebut akan lebih percaya diri 
dalam memecahkan masalah pada konteks yang lain. Hal ini juga sudah dilakukan oleh beberapa peneliti antara lain Agustinsa di tahun 2014, Sakif di tahun 2014 dan Wibawa di tahun 2014 (Kumalasari, dkk: 2016). Secara umum, berdasarkan hasil kajian dari beberapa penelitian tersebut diperoleh temuan bahwa defragmenting dapat memperbaiki struktur berpikir siswa menjadi struktur berpikir yang benar dalam menyelesaikan masalah matematika.

Juga ditunjang penelitian dari Fitri Kumalasari, Toto Nusantara, Cholis Sa'dijah Pendidikan Matematika Pascasarjana-Universitas Negeri Malang dalam judul Defragmenting Struktur Berpikir Siswa dalam Menyelesaikan Masalah Pertidaksamaan Eksponen. Pada penelitian ini defragmenting struktur berpikir dilakukan dengan menggunakan dua langkah, yaitu (1) identifikasi kesalahan berpikir dan (2) menata ulang pikiran yang salah menjadi benar. Pada langkah identifikasi kesalahan berpikir, peneliti akan melakukan wawancara terhadap hasil tes yang telah dilakukan untuk mengetahui proses berpikir subjek penelitian, kemudian peneliti akan membuat dan membandingkan struktur berpikir subjek penelitian dengan struktur masalah untuk melihat dan mengidentifikasi kesalahan berpikir pada subjek tersebut. Sementara itu, pada langkah menata ulang pikiran yang salah menjadi benar dilakukan proses disequilibrasi, conflict cognitive, serta scaffolding yang merujuk pada pernyataan Subanji (2015) yang mengungkapkan bahwa untuk memfasilitasi terjadinya defragmenting dapat dilakukan dengan menggunakan beberapa cara, seperti scaffolding, analisis proses konstruksi, conflict cognitive, dan disequilibrasi.

Disequilibrasi yang dilakukan peneliti adalah dengan memberikan pertanyaan-pertanyaan yang menimbulkan kecurigaan atau menimbulkan kesenjangan berpikir pada siswa sehingga siswa melakukan proses refleksi pada jawabannya. Conflict cognitive dilakukan peneliti kepada siswa ketika siswa mengalami kesalahan yang memerlukan suatu contoh yang bisa digunakan untuk membentuk suatu konflik sehingga akhirnya siswa akan berpikir ulang tentang jawabannya. Scaffolding adalah upaya pemberian bantuan yang berupa pertanyaan, petunjuk, pengingat, arahan, atau dorongan kepada siswa ketika siswa tersebut mengalami kesalahan dalam menyelesaikan masalah. Defragmenting yang diberikan oleh peneliti memerhatikan dan mengacu pada kesalahan prosedural yang dilakukan ketika subjek penelitian menyelesaikan masalah.

\section{PEMBAHASAN}

Dari beberapa penelitan defragmenting yang sudah pernah dilakukan belum pernah ada di Jakarta. Untuk itu sebagai peneliti literatur sangat tertarik dan akan mengembangkan penelitian ini dengan metode penelitian kuantitatif dari dua sekolah swasta sebagai tempat eksperimen. Dengan mengembangkan pola struktur berpikir defragmenting pada kegiatan belajar mengajar pada batasan materi tertentu .

Wibawa (2012: 165) mengatakan langkah- langkah yang dapat dilakukan pendidik dalam melakukan defragmenting struktur berpikir adalah :

1. Scanning ; pada tahap ini pendidik membuat gambaran peta kognitif mengenai proses berpikir siswa pada saat memecahkan masalah yang diberikan. Pada tahap ini pendidik membarikan masalah kepada siswa untuk bekerja memecahkan masalah sambil mengungkapkan secara keras apa yang dipikirkannya. Pada tahap ini pendidik tidak melakukan intervensi, membiarkan siswa bekerja dan mengungkapkan apa yang diapikirkan seperti ketika siswa mengalami kebingungan, siswa akan mengungkapkan bahwa "saya bingung disini" tugas pendidik hanyala mencatat, pada bagaian mana siswa tersebut mengalami kebingungan. Setelah siswabekerja. Barulah pendidik melakukan wawancara secara mendalam untuk mengungkapkan semua apa yang di pikirkan siswa. Proses berpikir siswa dapat di ketahui melaului prilaku yang tampak pada saat memecahkan suatu masalah, 
prilaku yang dimaksud adalah melalui tulisan verbal dan pengkomunikasian apa yang sedang dikerjakan.

2. Chek some errors; peneliti melakukan pengecekan pada bagian - bagian yang slah . tahap ini peneliti menentukan apa - apa yang menjadi sumber masalah. Apakah terjadi fragmentasi strutur berpikir? Apakah terdapat lubang pemahaman ? atau terdapat pemahaman yang masih samar - samar untuk diingat.

3. Repairing ; dilakukan perbaikan dan penataan sesuai dengan kesalahan yang terjadi. Perbaikan dan penataan di lakukan apabila kesalah yang terjadi karena subjek tidak memahami konsep dengan baik dan konsep-konsep yang dipikirkan tiak terhubung dengan baik .

4. Give a chance to re-works memberikan kesempatan pada siswa untuk mengerjakan kembali masalah yang dihadapi.

5. Certain the results memastikan bahwa jawaban yang diberikan benar dan mempertanyakan kembali apa yang dikerjakannya atau dipahaminya

Hal ini sejalan dengan pemecahan masalah polya (Wardhani, 2010) terdapat empat aspek kemampuan memecahkan masalah sebagai berikut:

1. Memahami masalah Pada aspek memahami masalah melibatkan pendalaman situasi masalah, melakukan pemilahan fakta-fakta, menentukan hubungan diantara fakta-fakta dan membuat formulasi pertanyaan masalah. Setiap masalah yang tertulis, bahkan yang paling mudah sekalipun harus dibaca berulang kali dan informasi yang terdapat dalam masalah dipelajari dengan seksama.

2. Membuat rencana pemecahan masalah Rencana solusi dibangun dengan mempertimbangkan struktur masalah dan pertanyaan yang harus dijawab. Dalam proses pembelajaran pemecahan masalah, siswa dikondisikan untuk memiliki pengalaman menerapkan berbagai macam strategi pemecahan masalah.

3. Melaksanakan rencana pemecahan masalah Untuk mencari solusi yang tepat, rencana yang sudah dibuat harus dilaksanakan dengan hati-hati. Diagram, tabel atau urutan dibangun secara seksama sehingga si pemecah masalah tidak akan bingung. Jika muncul ketidak konsistenan ketika melaksanakan rencana, proses haru ditelaah ulang untuk mencari sumber kesulitan masalah.

4. Melihat (mengecek) kembali Selama melakukan pengecekan, solusi masalah harus dipertimbangkan. Solusi harus tetap cocok terhadap akar masalah meskipun kelihatan tidak beralasan. Sedangkan kemampuan

Dalam pemecahan masalah matematika dibutuhkan kecermatan, kesabaran, dan pantang menyerah merupakan hal yang harus dimiliki dalam jiwa peserta didik, jika tidak ada maka perlu stimulus dari pendidik berupa kesempatan -kesempatan yang bisa di berikan untuk meningkatkan kembali rasa percaya diri peserta didik hingga mampu mengerjakan secara mandiri tanpa begantung dan terpengaruh dengan orang lain sehingga sifat pantang menyerah akan tertanam. Menurut Kartika, dkk (2016) Dengan mempertimbangkan bahwa kemampuan matematika siswa berada pada level yang beragam, soal-soal yang disajikan ketika guru mengawali suatu kegiatan belajar hendaknya dapat mengakomodasi keberagaman level pengetahuan siswa dan membuka peluang untuk mereka berpartisipasi dalam mengkonstruksi pengetahuan mereka. Demikian juga dengan mempertimbangkan bahwa konsep matematika adalah sesuatu (pengetahuan) yang abstrak dan untuk menuju pada keabstrakan tersebut pembelajar harus berpijak pada sesuatu (pengetahuan) yang konkrit yang dimilikinya. Pemanfaatan terhadap pengetahuan yang dimiliki siswa sesungguhnya membuka kesempatan kepada mereka untuk berperan aktif dalam kegiatan belajar, apakah bertanya, mengemukakan pendapat atau bekerja sama dengan temannya dalam kelompok belajar. Dengan kata lain pembelajaran matematika di kelas janganlah didominasi oleh guru, tetapi melibatkan siswa secara aktif. 


\section{SIMPULAN}

Metode pembelajaran defragmenting adalah metode baru dalam pendidikan, metode ini merupakan metode yang mampu mengkontruksi pola dalam berpikir menjadi lebih rapih seperti file - file yang semula tidak teratur menjadi rapih dan dengan mudah dapat diambil bila di perlukan. Sehingga dalam proses memecahkan masalah matematika akan lebih mudah menjawab soal-soal dengan cara yang kreatif dan inovasi dan cepat dikarenakan sudah diterapkan metode defragmenting dalam pembelajarannya. Mudah mengingat konsep yang sudah dipelajari dan memahami soal matematika dapat dipecahkan dengan penuh percaya diri.

\section{DAFTAR PUSTAKA}

Basuki, Ismet dan Haryanto. (2015) Asesmen Pembelajaran :Bandung. Pt Remaja Rosdakarya.

Hudojo, H. (2003). Pengembangan Kurikulum dan Pembelajaran Matematika. Malang: Universitas Negeri Malang. (2005). Kapita Selekta Pembelajaran Matematika. Malang: Universitas Negeri Malang.

Kumalasari,dkk. (2016). Defragmenting Struktur Berpikir Siswa dalam Menyelesaikan Masalah Pertidaksamaan Eksponen. Jurnal Pendidikan: Teori, Penelitian, dan Pengembangan,Volume: 1 Nomor: 2. Halaman: 246-255.

Liberna, H. 2015. Peningkatan Kemampuan Berpikir Kritis Matematis Siswa Melalui Penggunaan Metode Improve Pada Materi Sistem Persamaan Linear Dua Variabel.Jurnal Formatif 2(3): 190-197.

Suparman Ibrahim Abdullah .( 2015). Kompilasi D d dan Referensi Variable Kependidikan . Jakarta : R.D.I..Indonesia.

Uno, dkk.(2014). Variabel Penelitian dalam Pendidikan dan Pembelajaran. Jakarta: PT Ina Publikatama. Subanji. (2015). Teori Kesalahan Konstruksi Konsep dan Pemecahan Masalah Matematika. Malang: Universitas Negeri Malang.

Wahono, R.S.(2009). Defragmentasi Otak :Cara Cerdas Menjadi Cerdas Universitas Bangka Belitung. http://www.ubb.ac.id. Diakses 28 juni 2018

Wardhani, S., dkk.2010. Pembelajaran Kemampuan Pemecahan Masalah Matematika di SMP.PPPPTK Matematika, Yogyakarta.

Wibawa, K.A.(2012). Defragmenting Berpikir Psedo dalam Memecahkan Masalah Matematika.Yogyakarta: Deepublish. 